\title{
Literary Reading and Core Competence in Middle School English Class
}

\author{
Yanli Jia ${ }^{1, *}$ \\ ${ }^{1}$ School of Foreign Languages, Taishan University, Tai'an, Shandong, China \\ *Corresponding author.Email: jia_yanli@163.com
}

\begin{abstract}
With the reform development in middle school English teaching, the culturation of students' core competence has been given much importance in reading class, aiming to enhance the all-round individual competence. This article examines how to improve the core competence of middle school students in English reading classroom in terms of pre-class preparation, in-class reading comprehension, and text appreciation. This article is intended to provide a new avenue on the reform of middle school English reading teaching.
\end{abstract}

Keywords: Core competence, English literature, English teaching.

\section{INTRODUCTION}

Literary reading is closely related to core competence, because it can not only improve students' reading ability, but more importantly, cultivate students' emotional communication, critical thinking ability, logical thinking ability, cross-cultural communication ability and other core abilities required by core competence. Literary reading has attracted the attention of education circles at home and abroad. The core competence structure model proposed by the European Union clearly points out that literary reading can effectively promote students' ability to communicate in their mother tongue and foreign languages, as well as cultural awareness and expression. The Melbourne Declaration issued by Australia in 2008 provides strategic ideas and overall goals for the development of Australia's future education. It points out that it is necessary to strengthen the literary reading of primary and secondary school students, and cultivate their literacy, critical and creative thinking, and crosscultural skills. The United States formulated the 21st Century Literacy Framework in 2002 and updated it again in 2007, with particular emphasis on the important role of literary reading in cultivating students' core competence. In the National Core Curriculum of Basic Education promulgated by Finland, the importance of value education is particularly emphasized, and it is proposed that basic value education must be integrated into the teaching of various school courses, of which literary reading is a necessary part.

\section{RESEARCH BACKGROUND}

\subsection{Definition and Content of Core Competence}

"Core competence" refers to the necessary character and key abilities that students should have to meet the needs of life-long development and social development. It emphasizes personal cultivation, social care, family and country feelings, and pays more attention to independent development, cooperation and participation.

English literacy includes four aspects. Firstly, students need the necessary language skills, including listening, speaking, reading, and writing. Secondly, students should not only have language skills, but also have reasonable learning methods to improve learning efficiency. Thirdly, students need to understand the culture of other countries, establish a cross-cultural awareness on the basis of understanding the culture of their own country, and know how far away cultural differences are. Fourthly, students should gradually develop critical thinking skills and learn to solve specific problems. 


\subsection{The Rationale of the Study}

Based on the language ability and thinking characteristics of middle school students, this study aims at cultivating their core competence. The selection of classic foreign children's literary works in junior high school English reading teaching has dual meanings of theory and practice.

In terms of theory, through a series of teaching experiments, it has further verified the feasibility and effectiveness of children's literature in middle school English reading teaching, and provided theoretical guidance for middle school English reading teaching. It is helpful to solve the existing problems in theory, guide ideology and research methods of related research, and add more effective information and references to the research in this field, which will help attract more scholars to devote themselves to this area. Children's literature plays an important role in cultivating the critical thinking ability, logical thinking ability and autonomous learning ability of middle school students, and provides a new research perspective for the cultivation of middle school students' core competence research.

In terms of practice, the results of this research can be directly applied to middle school English reading teaching practice. This research is based on the psychological characteristics and cognitive development level of middle school students, combined with the teaching goals of English reading, shares teaching design and teaching strategies, and provides teaching practice reference for the application of children's literature in middle school English reading teaching, so that middle school English teachers can properly use children's literature in reading teaching, carry out effective teaching design, stimulate students' interest in English reading, help them form preliminary reading strategies, improve reading ability and independent thinking ability, thereby enhancing students' comprehensive use of language ability. Therefore, the application of children's literature in teaching makes the concept of core competence more concrete and improves the feasibility of core competence cultivation.

\section{PROBLEMS IN MIDDLE SCHOOL ENGLISH TEACHING AND LEARNING}

\subsection{Ignoring the Importance of Culture in English Learning}

The formation of each language is related to the country's culture, economic development level, and human history. Language and culture are closely related. Language is the carrier of culture, and cultural communication depends on language. The cultivation of cultural awareness is an indispensable part in foreign language teaching. Understanding foreign cultures is conducive to improving students' interest in learning English, their understanding of knowledge points, and their reading and communication skills. To a large extent, students' understanding of foreign cultures comes from teachers' teaching, and this knowledge is less presented in textbooks, which can easily lead to the ignorance of culture.

\subsection{Ignoring the Differences Between English and Chinese Thinking}

There is a big difference between Chinese and English in terms of expression and thinking. The most intuitive reflection is that the basic structure of sentences is different. Chinese generally starts from a human perspective, while English is generally more objective. The thinking habits of middle school students have not yet fully formed. Students will use directional thinking to learn knowledge points, which will affect their reading ability, writing ability, and communication ability.

\subsection{Weak Self-learning Ability}

Traditional Chinese education is more biased towards the "teaching" of teachers, and students are in a passive position in their learning. Many schools will not pay attention to the cultivation of students' autonomous learning ability because of their young age. Such an approach is inappropriate. Both the main body of learning and the center of the classroom should be students. If the cultivation of students' autonomous learning ability is neglected, it is difficult to realize the aim of making students become classroom masters. 


\section{THE IMPORTANCE OF LITERATURE IN MIDDLE SCHOOL ENGLISH READING CLASS}

\subsection{Improving Middle School Students' Interest in English Reading}

Middle school students are at the critical period of formation of logical thinking ability and critical thinking ability. Continuously stimulating students' interest in learning is the key. Students' ability to learn language is determined to a certain extent by their interest in English learning. The interesting and creative content of its content can effectively stimulate students' reading motivation, and a successful reading experience can help cultivate students' sustainable reading interest and make them give full play to their subjective initiative in English reading.

\subsection{Training Middle School Students' English Reading Strategies}

Children's literary works are different from the language students' daily learning. They will encounter various difficulties when reading. When using children's literary works for teaching, teachers imperceptibly convey to students the ways and means to solve dyslexia, and promote middle school students to form effective speculations and important English reading strategies such as predicting and integrating information in literary works.

\subsection{Improving the English Reading Ability of Middle School Students and Supplementing the Content of Teaching Materials}

Introducing the teaching of children's literary reading into the middle school English classroom can effectively supplement the content of the textbook, which is conducive to cultivating students' divergent thinking ability, thereby helping students to have a more complete understanding of the classroom teaching content, enhancing the reading effect, and cultivating students to use English thinking mode to learn English.

\section{METHODOLOGY}

\subsection{Subjects}

The research subjects of this study are 100 junior middle school students and an English teacher in two natural classes. Two parallel classes are used as experimental class and control class respectively. There are 50 students in each class, all around the age of 13. There are five English classes a week, and the students' English foundation is basically the same.

Before the start of the study, the English proficiency of the students in the two classes was tested with the final exam papers of the first semester, and the test results were analyzed.

\subsection{Methods}

At the early stage of the research, through a certain range of investigations, the researcher summarized the current problems in middle school English reading teaching, as well as the internal reasons behind these phenomena, and proposed possible solutions.

In order to ensure the authenticity of the teaching effect of children's literature to the utmost extent, before starting the experiment, the research tests the English reading ability of the students. After the experiment of teaching children's literature, the reading level and reading strategy of the students are again tested to see the actual effect of this new model.

In the research process, the researcher always adheres to the integration of theory with practice, emphasizes the exploratory and operability of research, adheres to practice, and combines the results of summarization with popularization and application.

\subsection{Data Collection}

In this study, the researcher will mainly use research tools such as classroom observation, pretest and post-test, questionnaire survey and individual interviews to collect and analyze data. It is expected that through these research tools, the researcher will communicate and analyze experimental results in a more intuitive and objective way. The following will detail the research tools that will be used in this study.

The main method of classroom observation used by the researcher is attending the class. The 
researcher invited 5 teachers in the second grade as observers to enter the experimental class and the control class. Each teacher observes 10 students and completes a 40-minute observation period. The teachers observe students' reading, discussion, expression and other classroom activities. The purpose is to verify the role of children's literary reading teaching in cultivating middle school students' interest in English reading by observing students' performance in the classroom.

In order to ensure the effectiveness of the experiment, both the experimental class and the control class use textbooks as the main teaching content. The experimental class adopts children's literary reading teaching method, while the control class adopts traditional teaching method. This experiment lasts for one academic year. After experiencing the teaching method of reading children's literature, both the experimental class and the control class will receive pre-test and post-test. The pre-test is mainly to understand the students' English foundation. The main purpose of the posttest is to verify whether the students' reading ability can be improved after adopting the children's literary reading teaching method, and to test whether the traditional teaching method and the children's literature teaching method will cause differences in the performance of the two classes of students. At the same time, another important purpose of the post-test is to test the teaching effect of reading children's literature.

The questionnaire survey is divided into two parts: a questionnaire survey for teachers and a questionnaire survey for students.

There are two questionnaires for teachers, one is about the attitude of middle school English teachers to reading teaching, and the other is about the main factor that affects the effective development of middle school reading teaching. The questionnaire for students also includes two copies, with 100 students in the experimental class and the control class. The first questionnaire was distributed and collected in the classroom before the experiment started. The main content focused on middle school students' reading attitude, ability, habits and interests, etc. The purpose was to understand the current situation of middle school students' English reading. After the experiment, the second questionnaire was mainly aimed at investigating the use of children's literature strategies in the reading process of middle school students, and the main purpose was to verify the role of children's literary reading teaching in cultivating middle school students' English reading strategies.

To a certain extent, individual interviews can make up for deep-seated problems that cannot be revealed by the questionnaire survey, and help the researcher have a deep understanding of the problems that the research needs to understand. In this study, the researcher will conduct individual interviews with 5 outstanding students and 5 students with academic difficulties in the experimental class and the control class before and after the experiment. Each interview is about 10 minutes. Interview before the experiment is mainly to understand the students' reading foundation. After the implementation of children's literary reading teaching method, the researcher will also interview these students again, the purpose of which is to verify the effectiveness and feasibility of children's literature in middle school English reading teaching.

\section{STAGES OF IMPLEMENTATION}

\subsection{The First Stage}

At this stage, both the experimental class and the control class are based on English published by Shandong Education Press (the first volume of grade seven) as the main textbook. In addition to the regular classroom teaching, the teacher also provides students with selected English children literary works. Students are required to read and discuss the works. The teacher gives appropriate explanations and guidance to help students to get a preliminary understanding of literary works, test their mastery through tests, and determine the second stage implementation plan through the analysis of test results.

\subsection{The Second Stage}

At the second stage, the experimental class and the control class still focus on teaching materials. In addition to the regular classroom teaching, the experimental class adopts selected English children's literature works for reading. The teacher divides the pre-selected works into three levels: low, medium, and high. The works in each level are also distinguished by difficulty according to the grading standard. According to the students' language ability, they are taught from "easy" to "difficult". At the same time, comprehensive activities are carried out in the experimental class with the help of reader theater, story king, work sharing and other methods. 
At the end of this stage, the second English reading ability test, questionnaire survey and interview will be conducted on the students, and the research report of the project stage will be completed.

\section{TEACHING STRATEGIES OF ENGLISH READING}

\subsection{Improving Students' Comprehension Abilities}

Strengthening the teaching of English literary works can comprehensively improve students' humanistic literacy, thereby laying a solid foundation for students' future development. At the current stage of middle school English teaching, teachers are required to help students with in-depth study through effective instruction in reading teaching. The teacher should improve students' learning ability and help them cultivate the ability to combine corresponding literary works to stimulate students' interest in learning, so that students can invest more time and energy in and after class, so as to develop good reading habits. This requires teachers to give full play to their role as guides, clarify the purpose of reading teaching in middle school English literature, and through targeted teaching to meet the actual reading needs of students and improve their reading level. In order to alleviate the tense learning atmosphere, teachers can strengthen the reading teaching of literary works through fun teaching and authentic language situation. They can also combine the corresponding film videos to help students further strengthen the understanding of literary story works.

\subsection{Improving Students' Critical Thinking Skills}

In the middle school English literary reading teaching, in order to comprehensively strengthen the cultivation of students' subject quality and thinking quality, teachers lead students to make corresponding plans to help students fully grasp the stock market complex character characteristics and beautiful language. In actual teaching activities, teachers need to be able to strengthen the thinking guidance of students and combine the literary elements of the corresponding character languages to create a good learning environment for students. Due to the large differences in students' learning abilities, teachers need to carry out curriculum design to stimulate students' interest in learning, continuously strengthen students' cultural awareness and thinking qualities, and thereby improve students' language skills. Teachers can also lead students in unit reading. To enhance students' ideological understanding, students are required to make reading notes, so as to help them further strengthen reading and understanding, deeply appreciate the beauty of language and the ingenuity of ideas in literary works, and comprehensively cultivate their language ability and cultural awareness.

\subsection{Text Appreciation}

In addition to strengthening the teaching of basic knowledge, teachers also need to lead students through corresponding exercises to continuously promote the development of students' thinking, help students carry out deeper learning, improve students' learning effects, and cultivate students' subject quality. Teachers can also use task-based teaching methods to help students construct corresponding mind maps, so that students can generate effective thinking collisions in the process of communication between groups, and help students gradually internalize corresponding literary works. In order to help students better grasp the text, teachers can also combine corresponding practical activities to fully mobilize students' enthusiasm and initiative, so that students can further understand on the basis of reading comprehension, and deeply experience the language and artistic charm of literary works. Teachers should fully strengthen the learning and application of literary language in a real situation. In the process of sharing and communication, students have a deep understanding of the differences between Chinese and Western cultures and in-depth analysis of the connotation of Western culture. Teachers guide students to deeply analyze the characters in literary works and give full play to students' desire for expression. In this process, students can deeply grasp the plot of the story, enhance the quality of thinking, and improve the learning effect.

\section{CONCLUSION}

In the teaching of English literary works in middle schools, teachers should strengthen summary and feedback based on the actual learning situation of students, and help students develop good learning habits. Teachers should also make full use of students' desire for expression to create reading classrooms in colleges and universities. In order to mobilize the enthusiasm of students, teachers can also encourage students to study with a 
critical eye, let students have a deep perception of the objective world, and strengthen the cultivation of students' core competence.

The middle school stage is the period for the formation of students' learning skills and learning habits. Teachers' words and deeds have a significant influence on the formation of students' learning ability. During this period, middle school students often imitate the teacher's behavior as a template to develop their own learning methods. Therefore, English teachers should set a good example in the classroom and use their own core learning concepts to subtly influence. Teachers should create a differentiated teaching environment based on different teaching content. This requires English teachers to have a strong control over English, integrate with students, and bring students into the teaching environment created for teaching in the classroom. Teachers should let students take the initiative to explore and discover the charm and mystery of the English subject, to maximize the use of the learning environment to improve learning efficiency and cultivate the core competence of students.

In middle school English teaching, the teaching method should closely follow the students' energetic and curiosity characteristics, cultivate students' interest in learning, and change from teacher-oriented passive teaching to studentoriented active learning, so that students can express their views, ask questions under the reasonable guidance of teachers. In addition, it can also appropriately expand the study of extracurricular articles, encourage various forms of learning based on the content of the article, such as textbook drama performances, recitation competitions, etc., and adjust teaching methods flexibly, allowing students to understand and learn knowledge in the practice of extracurricular activities, and improve learning efficiency.

The most basic function of language is communication, so teachers must pay special attention to the output process. The teacher's practical and appropriate classroom language creates a language learning environment for students invisibly. Teachers should help students truly know how to use language to communicate and appreciate the fun and significance of language communication, which has a very important impact on language learning. Teacher should encourage students to talk more, eliminate their anxiety in learning spoken English, and help them form a situation in which they dare to speak and love to speak English. For those timid and introverted students, teachers should encourage more, help build self-confidence in English communication, make every student actively participate, and improve students' oral communication skills.

\section{AUTHORS' CONTRIBUTIONS} Jia.

This paper is independently completed by Yanli

\section{REFERENCES}

[1] Berzonsky, M. D. "A social-cognitive perspective on identity construction". In Handbook of Identity Theory and Research. New York: Springer, 2011.

[2] Hamers, J. F. \& Blanc, H. A. Bilinguality and Bilingualism [M]. Cambridge: Cambridge University Press, 1989.

[3] Myron, W. Lustig \& Jolene Koester. Intercultural Competence: Interpersonal Communication across Cultures [M]. Shanghai Foreign Language Education Press, 2007.

[4] Rod Ellis. An Introduction to Second Language Acquisition. Oxford: Oxford University Press, 2008.

[5] Yihong Gao, Ying Cheng, Yuan Zhao et al. English Learning and the Change of Selfidentification-A Quantitative Investigation of University Students [J]. Foreign Language Teaching and Research, 2003, 35(2): 132-139.

[6] Zoltan Dornyei. The Psychology of Second Language Acquisition. Oxford: Oxford University Press, 2013. 